\title{
Program to Manage New and Expensive Drugs in Pediatrics: Profile of a New Drug Policy and a 12-Month Descriptive Study
}

\author{
Jennifer Corny, Camille Cotteret, Élaine Pelletier, Philippe Ovetchkine, and Jean-François Bussières
}

\begin{abstract}
Background: With growing financial pressure and the range of new and expensive drugs, hospital administrators, clinicians, and pharmacy directors are facing tough decisions on how to manage drug budgets. At a Canadian mother-child hospital, a policy for new and expensive drugs was developed, with the goal of managing their use and costs.

Objectives: To describe the development and implementation of a policy for new and expensive drugs in a mother-child teaching hospital and to describe the profile of requests for these therapies over a 12-month period.

Methods: A brainstorming session was conducted with members of the pharmacy and therapeutics committee to define the criteria for new and expensive drugs at the study hospital and a new process to evaluate requests for these drugs. Over the 12-month period following implementation of the policy, all requests for new and expensive drugs were evaluated through collection and analysis of relevant data.

Results: The new drug policy was launched on October 1, 2014. Over the following 12-month period, a total of 58 requests for new and expensive drugs were discussed, but only 47 request forms were completed and signed by a physician and a clinical pharmacist.

Conclusions: New and expensive drugs represent a challenge for clinicians and hospital stakeholders. This study illustrates the implementation of a new policy for these drugs in a mother-child teaching hospital over a 12-month period.
\end{abstract}

Keywords: drug policy, emerging drugs, management program, off-label use, pediatrics

\section{Can J Hosp Pharm. 2017;70(5):358-67}

\section{RÉSUMÉ}

Contexte : Les budgets de plus en plus serrés et la gamme de médicaments nouveaux ou coûteux placent les administrateurs, les cliniciens et les directeurs de pharmacie des hôpitaux devant des décisions difficiles en ce qui touche la gestion des dépenses en médicaments. On a mis au point, dans un hôpital canadien mère-enfant, une politique concernant les médicaments nouveaux ou coûteux avec pour objectif de gérer leur utilisation et leurs coûts.

Objectifs : Décrire l'élaboration et la mise en place d'une politique sur les médicaments nouveaux ou coûteux dans un hôpital universitaire mère-enfant et décrire le profil des demandes pour ces pharmacothérapies sur une période de 12 mois.

Méthodes : Les membres du comité de pharmacologie ont procédé à une séance de remue-méninges dans le but de définir les critères pour les médicaments nouveaux ou coûteux dans l'hôpital à l'étude et un nouveau processus servant à évaluer les demandes pour ces médicaments. Au cours des 12 mois suivant la mise en place de la politique, toutes les demandes pour des médicaments nouveaux ou coûteux ont été évaluées à l'aide d'une cueillette et d'une analyse de données pertinentes.

Résultats : La nouvelle politique sur les médicaments a été lancée le $1^{\text {er }}$ octobre 2014. Au cours des 12 mois suivants, un total de 58 demandes pour des médicaments nouveaux ou coûteux ont été analysées, mais seulement 47 formulaires de demande ont été remplis et signés par un médecin et un pharmacien clinicien.

Conclusions : Les médicaments nouveaux ou coûteux représentent un défi pour les cliniciens et les parties prenantes des hôpitaux. La présente étude décrit la mise en place d'une nouvelle politique pour ces médicaments dans un hôpital universitaire mère-enfant sur une période de 12 mois.

Mots clés : politique sur les médicaments, médicaments émergents, programme de gestion, emploi non conforme, pédiatrie 


\section{INTRODUCTION}

$\mathrm{T}$ The Canadian Institute for Health Information has reported that, in 2014, Canadians spent an estimated $\$ 29.4$ billion on prescribed drugs purchased in retail pharmacies. ${ }^{1}$ This total does not include spending on drugs dispensed in hospitals or those funded through cancer agencies and other special programs. A complementary evaluation of drugs dispensed in Canadian hospitals in 2014 (for all provinces except Quebec) estimated the cost to be about $\$ 2$ billion dollars. ${ }^{1}$ In Quebec, drugs used in hospitals represent on average $5.3 \%$ of hospital expenditures. ${ }^{2}$ Although the growth in spending for prescribed drugs has slowed in both the public and private sectors since the year 2000, hospitals are struggling with insufficient public funding to cover the costs of innovative and expensive drugs throughout the country. ${ }^{3}$

In Canada, responsibility for health care is shared between the federal and provincial governments. The contents of outpatient and hospital drug lists are determined by provincial authorities, whereas notices of compliance for new drugs are issued by the federal government. Both outpatient (retail) and hospital drug lists may include specific criteria for the use of a particular drug, and prescribers are expected to comply with these criteria. Failure to do so may lead to the withholding of reimbursement by payers, such as private and public drug plans for outpatient prescriptions and the provincial ministries of health for drugs used in the hospital setting.

In hospitals, a drug is added to the institutional formulary following a review by and positive recommendation from the pharmacy and therapeutics committee and the director of the pharmacy department. ${ }^{4,5}$ Such recommendations are based on a thorough review of the literature to determine drug safety and efficacy. Hospital formularies, which have been in place since the early 1940s in North America, are usually closed lists, having a limited selection of drugs relative to the wide range of products available on the retail market. Such limited selection is based on patient safety, as well as practical considerations and economic objectives. The formulary is usually adapted to each hospital's patient profile, but some provinces, such as British Columbia, have created a provincial authority with a single formulary for all hospitals.

With growing financial pressures and the range of new and expensive drugs, hospital administrators, clinicians, and pharmacy directors are facing tough decisions on how to manage their drug expenditures. Hospital budgets in most Canadian provinces are based on the prior year's expenditures, indexed annually to the increase in cost of living over the preceding year. The drug budget is part of the overall hospital budget, and any increase in drug expenditures above the annual cost-of-living index may result in financial and service cuts in other patient care areas. To help control the use of new and expensive drugs, the pharmacy and therapeutics committee often requires that prescribers complete a nonformulary request form to justify the use of new or unlisted products. Such administrative measures are in place in most hospitals and may be required by provincial legislation. The administrative process usually requires the prescriber to provide a description of the drug order, the indication, and a brief justification for the use of any nonformulary drugs. Nonformulary requests are evaluated by a pharmacist, who approves or denies use of the drug. In case of a refusal, an alternative drug listed on the hospital's formulary is proposed and dispensed.

To help manage the use and cost of new and expensive drugs at the study hospital, a new drug policy was developed and implemented, ${ }^{6-8}$ and its use over a 12 -month period was evaluated. The aim of this study was to describe implementation of the new policy in this hospital and to describe the profile of requests for such therapies over a 12-month period.

\section{METHODS}

\section{Study Setting}

This descriptive cross-sectional study was conducted in a 500-bed mother-child teaching hospital located in Montréal, Quebec. On December 31, 2015, the hospital's formulary listed a total of 3468 drug formulations, and the annual drug budget was more than Can $\$ 28$ million. The Pharmacy and Therapeutics Committee consisted of 4 pharmacists (the departmental director [J.F.B.], the pharmacy and therapeutics pharmacist, the antimicrobial stewardship pharmacist, and the risk management pharmacist), 5 physicians (e.g., representing pediatrics, obstetricsgynecology, hematology-oncology, anesthesiology, infectious diseases, intensive care unit), and 1 nurse. Nonformulary requests were presented and discussed regularly at meetings of this committee. Repeat requests for a given nonformulary drug would lead to a formal evaluation of the requested drug and its potential addition to the formulary.

\section{Policy for New and Expensive Drugs}

A brainstorming session was conducted with members of the Pharmacy and Therapeutics Committee to identify key information that was not covered by the existing nonformulary request form and to develop a new request form for new and expensive drugs. The brainstorming session was also useful for identifying the criteria used to define a drug as new or expensive at the study hospital.

For the purpose of this study and the new drug policy, a new or expensive drug was defined as a drug imported from another country through Health Canada's Special Access Programme and/or a drug intended for an off-label use with limited scientific evidence in adult and (more specifically) pediatric populations and/or an expensive drug (e.g., $\geq$ Can $\$ 300 /$ dose). Health Canada's Special Access Programme allows prescribers to use a drug not currently marketed in Canada for patients with serious or life-threatening conditions when conventional therapies cannot be used. 
The new policy for new and expensive drugs was approved by the hospital's Pharmacy and Therapeutics Committee and Ethics and Research Committee on October 1, 2014.

\section{2-Month Profile of Use of New and Expensive Drugs}

All verbal and written requests for new and expensive drugs were evaluated during a 12-month study period (October 1, 2014, to September 30, 2015). For each drug order fulfilling the inclusion criteria, a research assistant (J.C. or C.C.) working part-time on this new process was contacted (usually by a clinical pharmacist) and became involved. The pharmacy director (J.F.B.) presented the new drug policy to the prescribing physician and the clinical pharmacist, who worked together to complete the request form for new and expensive drugs, with the help of the research assistant if needed. When appropriate, an interdisciplinary meeting was suggested to broaden the discussion to include other clinicians. The research assistant helped in retrieving the relevant scientific literature and answering questions about the policy. Once the request form was completed, the research assistant reviewed the form to ensure accuracy of completion. At that point, the physician or pharmacist solicited approval from the medical director and the pharmacy director before adding the completed form to the patient's health care record for further steps in procuring and administering the drug. Requests that were refused by the medical director or pharmacy director were brought to the Pharmacy and Therapeutics Committee and the executive board of directors for additional review and a final decision. If use of the drug was approved, the request form was faxed to the pharmacy department with a valid drug order. The research assistant then entered the variables detailed in the request form into an anonymized spreadsheet database (MS Excel, Microsoft, Redmond, Washington) for follow-up and analysis.

The following variables were collected from the request form for new and expensive drugs: patient file number, current clinical conditions to be treated, generic and commercial names of the requested drug, strength and formulation of the requested drug, level of available scientific evidence supporting use of the requested drug for the targeted indication (i.e., randomized controlled or clinical trials, defined as level 1 evidence; observational studies, specifically cross-sectional studies, case-control studies, cohort studies, longitudinal studies, and/or ecological studies, defined as level 2 evidence; case reports, defined as level 3 evidence; or expert opinion, defined as level 4 evidence), level of evidence in pediatrics (either extrapolation from adult studies, defined as level "a", or results from pediatric studies, defined as level "b"), patient's history of previous drug treatment, place in therapy for the requested drug (first-line, second-line, third-line, or fourth-line and beyond), details of the order for the requested drug (e.g. dose, frequency, route, duration of therapy, other modalities), targeted efficacy and safety end points, confirmation that the patient/parent has given informed consent, and signatures of the physician and pharmacist, as well as the medical director. Targeted efficacy and safety end points (e.g., platelets $>50 \times 10^{9} / \mathrm{L}$ for a patient with thrombocytopenia) were defined by a physician and a clinical pharmacist using literature review, and were revised or completed in the database by the research assistant. These end points were standardized for frequently used emerging drugs and adapted for rarely used ones (or according to the patient's clinical and/or biological state). The prescribing physician obtained informed consent from the patient/parent before completing the request form.

The following variables were collected from the patient file: presence of the fully completed request form for new and expensive drugs, time of administration of the first dose of each requested drug, status of efficacy and safety end points (with dates), occurrence of side effects, physician's medical notes about follow-up monitoring for the requested drug, and any other relevant information for monitoring use of the requested drug. Relevant data for patients included during the defined study period were collected until January 31, 2016.

The time and date of the initial verbal request were also noted and collected. The cost of doses of new and expensive drugs was extracted from the hospital's drug procurement information system (GRM, Logibec, Montréal, Quebec). For drugs that were used for a limited period, the total drug cost was calculated according to the total number of doses administered, even if treatment was completed after the end of the study period. For drugs intended for long-term administration, the total drug cost was calculated for a 12-month period, no matter when the drug was initiated during the study period.

Following data entry in the spreadsheet, data were extracted for analysis and to provide a descriptive profile of the request form for new and expensive drugs and the safety and efficacy end points. Only descriptive statistical analyses were performed.

\section{RESULTS}

\section{Implementation of the New Policy}

The new drug policy was launched at the study hospital on October 1, 2014. Information about implementation of the new drug policy was also sent by e-mail to all physicians, medical residents, pharmacists, pharmacy residents, and nurses in the hospital. A formal oral presentation was given at a meeting of the Council of Physicians, Dentists and Pharmacists in November 2014. Further presentations were given in at least 4 medical departments (hematology-oncology, pediatrics, surgery, and intensive care). Positive reinforcement was provided by various medical authorities within the organization in December 2014. The policy was also presented and discussed at a few pharmacy department meetings, and clarifications were provided individually whenever requested. 
Appendix 1 (available at www.cjhp-online.ca/index.php/ cjhp/issue/view/123/showToc) shows an example of the request form for new and expensive drugs. Both the request form and a validated example of a completed form were posted on the hospital's intranet to facilitate completion of the form by prescribers and clinical pharmacists.

\section{2-Month Profile of Use of New and Expensive Drugs}

Between October 1, 2014, and September 30, 2015, a total of 58 requests for new and expensive drugs were discussed, but only 47 request forms were completed and signed by a physician and a clinical pharmacist. All of the 47 request forms completed and signed by physicians were approved by the director of the pharmacy department. Of the remaining 11 forms, discussion between physicians and clinical pharmacists led to a change in therapy (e.g., to use a drug already on the hospital formulary). Among the 47 approved requests, doses related to 4 requests were not administered at the study hospital, either because the patient was transferred to another hospital or to the ambulatory setting or because the patient experienced deterioration that prevented administration of the drug. Therefore, doses were administered at the study hospital for a total of 43 approved requests, and no doses were administered at the study hospital for a total of 15 of the initial requests.

The initial 58 requests for new or expensive drugs concerned a total of 48 patients with a median age of 8 years (range $0-18$ years). The requests originated from hematology-oncology $(n=31[53 \%])$, outpatient clinics $(n=9[16 \%])$, and other patient care areas $(n=18[31 \%])$.

A total of 28 new or expensive drugs were requested during the study period: alpha-glucosidase, anakinra, biotin, blinatumomab, bortezomib, canakinumab, clofarabine, defibrotide, eculizumab, everolimus, imatinib, infliximab, memantine, metaiodobenzylguanidine (also known as MIBG), ofatumumab, peginterferon alfa-2b, picibanil, ponatinib, rituximab, romiplostim, ruxolitinib, sorafenib, tetrodotoxine, thiotepa, tocilizumab, treprostinil, ustekinumab, and vedolizumab.

Table 1 presents the 12 -month profile of requests for new and expensive drugs initiated between October 1, 2014, and September 30, 2015. Of the 58 initial requests for new or expensive drugs, 18 (31\%) were related to the Special Access Programme, 36 (62\%) were for off-label uses, and $3(5 \%)$ were for expensive drugs; for the remaining 1 request (2\%), the type of request was unknown. New or expensive drugs were prescribed for a total of 30 clinically distinct indications. New or expensive drugs were requested for use as first-line therapy in $16(28 \%)$ of the 58 cases, as second-line therapy in 4 (7\%), as third-line therapy in 17 (29\%), and as fourth-line therapy or beyond in 15 (26\%); data on intended place in therapy were missing for 6 $(10 \%)$ of the 58 requests.
Of the 58 initial requests for new or expensive drugs, an average \pm standard deviation of $3.1 \pm 1.5$ efficacy end points (minimum 1, maximum 7) and an average of $2.3 \pm 2.6$ safety end points (minimum 0, maximum 12) were reported. Following administrative approval, treatment plans were modified for $11(26 \%)$ of the 43 requests with doses administered in the study hospital; these modifications were related to a dose increase $(n=8[73 \%])$, a dose reduction $(n=1[9 \%])$, or an increase in duration of therapy $(n=2[18 \%])$.

Of the 47 approved requests, the level of scientific evidence was randomized controlled or clinical trials for 21 (45\%), observational studies for $6(13 \%)$, case reports for $14(30 \%)$, and expert opinion for 2 (4\%). This scientific evidence was extracted from pediatric studies for 33 requests $(70 \%)$ and was extrapolated from adult studies for 10 requests (21\%). For 4 requests (9\%), data on the level of evidence and its source were missing.

Of the 47 approved requests, the average delay between the intention to treat and administration of the first dose was $13.7 \pm 29.9$ days. Across all cases in which costs could be calculated, the total cost of new and expensive drugs used in the study period was estimated at Can $\$ 1019365$ (average $\$ 26138 \pm \$ 67237$, minimum \$29, maximum \$349 565).

Table 2 presents the profile of efficacy and safety end points for the 43 new and expensive drugs that were actually administered at the study hospital during the study period. A total of 122 efficacy end points were identified, and targeted efficacy was achieved in 23 (59\%) of the 39 cases for which data were available ( 4 cases had some missing data). In addition, a total of 91 safety end points were identified, and in 14 (33\%) of the 43 cases, the patients experienced side effects, mainly an increase in liver enzymes, hematologic side effects, dizziness, and fatigue.

\section{DISCUSSION}

This cross-sectional study describes an original drug policy designed to help manage and constrain the use of new and expensive drugs in a mother-child teaching hospital in Canada.

Over a 12-month period, 58 requests for new and expensive drugs were initiated; the requests involved a total of 28 drugs intended for the treatment of 48 patients, mainly for hematologyoncology indications (53\%). This is a limited number of requests, considering the size of the hospital (500 beds), its teaching mission, and the number of drug transactions (about 1.5 million/year). Although completion of the request form for new and expensive drugs is demanding and time-consuming, it appears to be a reasonable burden for prescribers, given the relatively small number of requests observed in the first year.

The hospital's policy for managing new and expensive drugs was developed to support the decision-making process in 3 different situations: $62 \%$ of the requests were for off-label uses, $31 \%$ were for drugs covered by Health Canada's Special Access Programme, and $5 \%$ were for expensive drugs. In a mother-child 
This single copy is for your personal, non-commercial use only.

For permission to reprint multiple copies or to order presentation-ready copies for distribution, contact CJHP at publications@cshp.ca

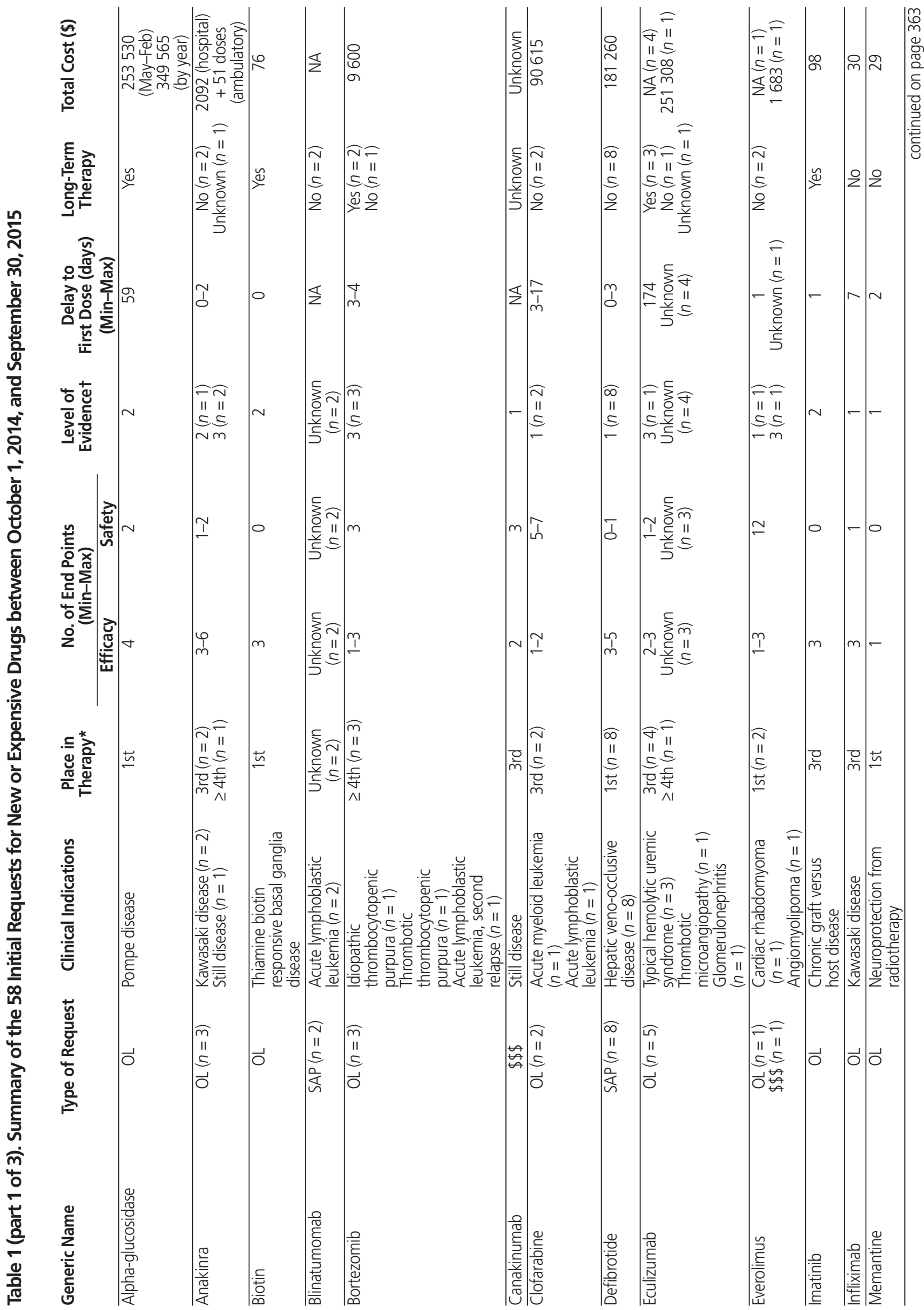




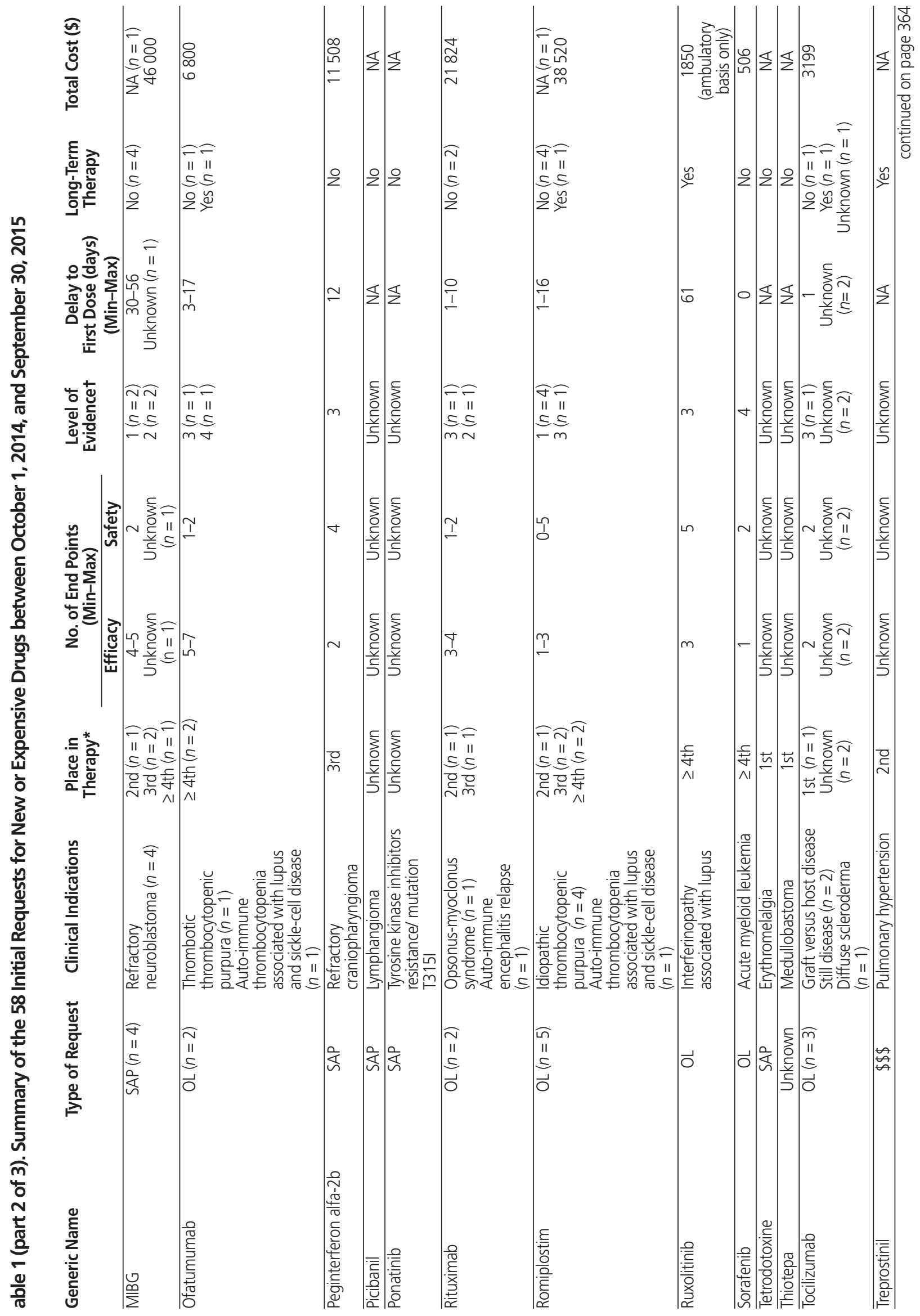




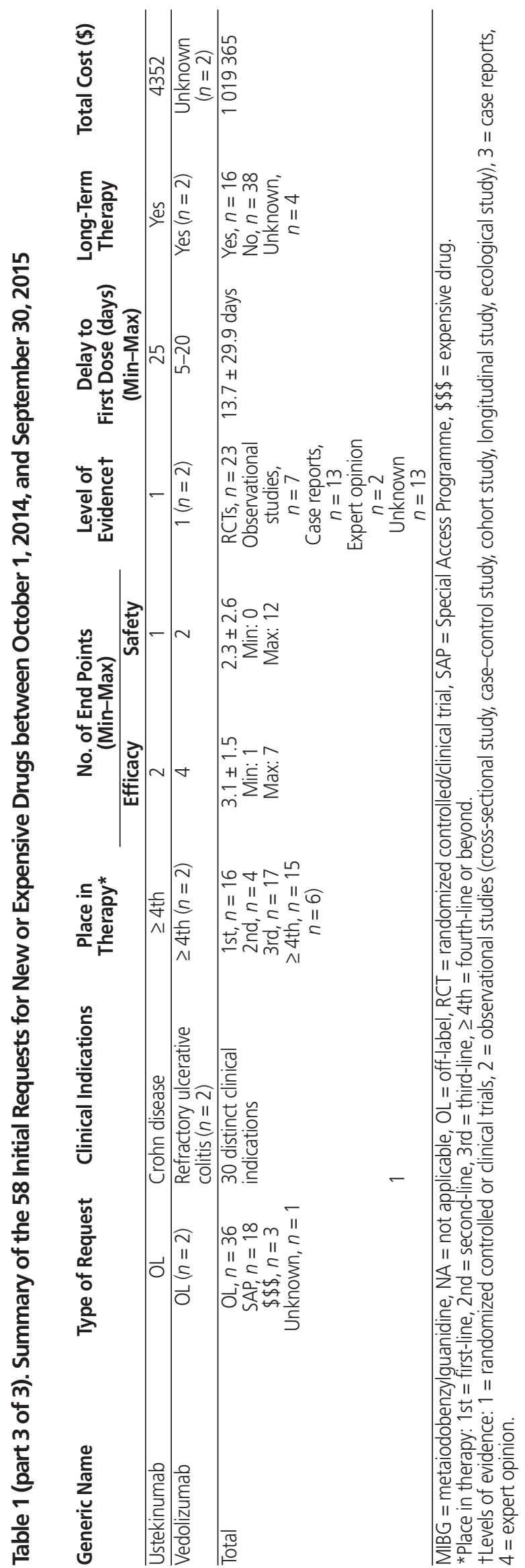

hospital, off-label drug use is more common than in adult hospitals. Importation of drugs that have not yet been approved in Canada but are available in other countries should remain an option in tertiary care hospitals. Some drug manufacturers do not complete a new drug submission for a drug already commercialized in another country, such as the United States, France, or the United Kingdom. This omission leaves children without appropriate treatment for some indications. The need to import a drug remains unavoidable in some circumstances. However, such exceptional use should not become a systematic bypass of regulatory approval. The request form for new and expensive drugs can help to limit the potential abuse of exceptional drug access programs, even if physicians are aware of the civil and professional liabilities they face when they prescribe a nonapproved drug. The request form for new and expensive drugs could also contribute to prescribers' education about these responsibilities.

Over the study period, new and expensive drugs were used in roughly equal proportions as third-line (29\%), first-line (28\%) and fourth-line (26\%) therapy. Although the new and expensive drugs were generally planned for use as alternatives to established drug treatments, they were sometimes used as first-line therapy in very specific cases. For instance, defibrotide appeared to be a first-line option for severe hepatic veno-occlusive disease in oncology patients; this drug is not yet approved for use in Canada, but is available in Europe and the United States. Although alpha-glucosidase is indicated for the treatment of Pompe disease, its application is limited to a targeted age group and clinical conditions. Interestingly, the level of scientific evidence was limited, with randomized controlled or clinical trials for only $40 \%$ of requests; observational studies, case studies, and expert opinion were used for $12 \%, 22 \%$, and $3 \%$ of requests, respectively. Scientific evidence was obtained from pediatric studies in $70 \%$ of cases, and had to be extrapolated from adult studies for the remaining $21 \%$ (with data missing for $9 \%$ ).

The decision to use a new or expensive drug is usually associated with a certain level of uncertainty: the prescriber is typically not familiar with the drug, the patient's condition is critical and may deteriorate, the literature is limited, and there are grey zones. Implementation of the new policy at the study hospital showed that it is possible to appropriately supervise and rationalize the use of these drugs, as $19 \%$ of the initial requests were withdrawn after discussion of possible alternatives between physicians and clinical pharmacists. Moreover, objective end points were defined and could be used to help the team re-evaluate use of the drug. Targeted efficacy was achieved in 59\% of the cases with suitable data, and side effects were proactively identified in $33 \%$ of cases.

Aside from the clinical justification for using a new or expensive drug, the request form developed through this initiative allowed a stepwise approach to providing patients with explicit information about clinical uncertainty and exceptional use of the 
Table 2 (part 1 of 2). Summary of Efficacy and Safety End Points for New and Expensive Drugs Administered between October 1, 2014, and September 30, 2015*

Efficacy

\begin{tabular}{|c|c|c|c|c|c|}
\hline \multirow[b]{2}{*}{ Generic Name } & \multirow[b]{2}{*}{ Patient ID No. } & & \multirow[b]{2}{*}{$\begin{array}{c}\text { No. (\%) of Safety } \\
\text { End Points Monitored }\end{array}$} & \multirow[b]{2}{*}{$\begin{array}{c}\text { Presence and } \\
\text { Type of Side Effects }\end{array}$} \\
\hline & & $\begin{array}{l}\text { No. (\%) of End } \\
\text { Points Monitored }\end{array}$ & $\begin{array}{c}\text { Targeted Efficacy } \\
\text { Achieved }\end{array}$ & & \\
\hline Alpha-glucosidase & 31 & $3 / 4(75)$ & Yes & $2 / 2(100)$ & No \\
\hline \multirow[t]{3}{*}{ Anakinra } & 18 & $6 / 6(100)$ & Yes & $1 / 1(100)$ & No \\
\hline & 28 & $3 / 3(100)$ & Yes & $1 / 1(100)$ & No \\
\hline & 42 & $6 / 6(100)$ & Yes & $1 / 2(50)$ & No \\
\hline Biotin & 4 & $2 / 3(67)$ & Unknown & No safety end points & NA \\
\hline \multirow[t]{3}{*}{ Bortezomib } & 11 & $2 / 3(67)$ & Yes & $3 / 3(100)$ & $\begin{array}{c}\text { Yes }(n=1) \\
\text { Thrombocytopenia }\end{array}$ \\
\hline & 17 & $1 / 1(100)$ & No & $2 / 3(67)$ & No \\
\hline & 6 & $2 / 2(100)$ & Yes & $2 / 3(67)$ & No \\
\hline Canakinumab & 43 & $1 / 2(50)$ & Unknown & $0(0 / 3)$ & NA \\
\hline \multirow[t]{2}{*}{ Clofarabine } & 2 & $1 / 1(100)$ & No & $7 / 7(100)$ & No \\
\hline & 17 & $2 / 2(100)$ & No & $5 / 5(100)$ & No \\
\hline \multirow[t]{7}{*}{ Defibrotide } & 14 & $5 / 5(100)$ & No & $0 / 1(0)$ & No \\
\hline & 19 & $4 / 4(100)$ & Yes & $1 / 1(100)$ & No \\
\hline & 33 & $5 / 5(100)$ & Yes & $1 / 1(100)$ & No \\
\hline & 34 & $3 / 3(100)$ & Yes & $1 / 1(100)$ & No \\
\hline & 38 & $4 / 4(100)$ & Yes & $1 / 1(100)$ & No \\
\hline & 44 & $4 / 4(100)$ & Yes & $1 / 1(100)$ & No \\
\hline & 45 & $4 / 4(100)$ & Yes & No safety end points & NA \\
\hline Eculizumab & 25 & $2 / 3(67)$ & Yes & $1 / 1(100)$ & $\begin{array}{l}\text { Yes }(n=1) \\
\text { Headaches }\end{array}$ \\
\hline Everolimus & 5 & $3 / 3(100)$ & Yes & $12 / 12(100)$ & $\begin{array}{l}\text { Yes }(n=1) \\
\text { Neutropenia }\end{array}$ \\
\hline Imatinib & 23 & $2 / 2(100)$ & No & $4 / 4(100)$ & No \\
\hline Infliximab & 18 & $3 / 3(100)$ & No & $1 / 1(100)$ & No \\
\hline Memantine & 3 & $1 / 1(100)$ & Yes & No safety end points & NA \\
\hline \multirow[t]{3}{*}{$\overline{\mathrm{MIBG}}$} & 10 & $4 / 5(80)$ & No & $1 / 2(50)$ & No \\
\hline & 46 & $1 / 4(25)$ & Unknown & $2 / 2(100)$ & Yes $(n=1)$ \\
\hline & 47 & $3 / 4(75)$ & Yes & $2 / 2(100)$ & $\begin{array}{c}\text { Neutropenla } \\
\text { Yes }(n=2) \\
\text { Neutropenia, } \\
\text { thrombocytopenia }\end{array}$ \\
\hline \multirow[t]{2}{*}{ Ofatumumab } & 11 & $5 / 5(100)$ & Yes & $1 / 1(100)$ & \multirow{2}{*}{$\begin{array}{c}\text { Yes }(n=1) \\
\text { Capillary leak syndrome } \\
\text { No }\end{array}$} \\
\hline & 22 & $7 / 7(100)$ & Yes & $2 / 2(100)$ & \\
\hline Peginterferon alfa-2b & 37 & $2 / 2(100)$ & No & $4 / 4(100)$ & $\begin{array}{c}\text { Yes }(n=1) \\
\text { Fatigue, fever, headaches }\end{array}$ \\
\hline \multirow[t]{2}{*}{ Rituximab } & 24 & $3 / 3(100)$ & Yes & $2 / 2(100)$ & No \\
\hline & 40 & $3 / 4(75)$ & Yes & $1 / 1(100)$ & $\begin{array}{c}\text { Yes }(n=1) \\
\text { Dizziness/weakness } \\
\text { after infusion }\end{array}$ \\
\hline \multirow[t]{4}{*}{ Romiplostin } & 2 & $1 / 1(100)$ & No & $1 / 1(100)$ & No \\
\hline & 22 & $1 / 1(100)$ & Yes & $4 / 4(100)$ & No \\
\hline & 30 & $1 / 1(100)$ & No & $2 / 2(100)$ & No \\
\hline & 6 & $1 / 1(100)$ & Yes & $4 / 4(100)$ & No \\
\hline Ruxolitinib & 1 & $3 / 3(100)$ & Yes & $5 / 5(100)$ & $\begin{array}{c}\text { Yes }(n=1) \\
\text { Liver enzyme increase }\end{array}$ \\
\hline Sorafenib & 12 & $1 / 1(100)$ & No & $2 / 2(100)$ & $\begin{array}{c}\text { Yes }(n=1) \\
\text { Liver enzyme increase }\end{array}$ \\
\hline Thiotepa & 41 & Unknown & Unknown & Unknown & Unknown \\
\hline \multirow[t]{3}{*}{ Tocilizumab } & 2 & $2 / 2(100)$ & No & $2 / 3(67)$ & $\begin{array}{c}\text { Yes }(n=1) \\
\text { Consciousness disorder }\end{array}$ \\
\hline & 43 & Unknown & No & Unknown & $\begin{array}{c}\text { Yes }(n=1) \\
\text { Allergic reaction }\end{array}$ \\
\hline & 48 & Unknown & No & Unknown & No \\
\hline
\end{tabular}


This single copy is for your personal, non-commercial use only.

For permission to reprint multiple copies or to order presentation-ready copies for distribution, contact CHHP at publications@cshp.ca

Table 2 (part 2 of 2). Summary of Efficacy and Safety End Points for New and Expensive Drugs Administered between October 1, 2014, and September 30, 2015*

\begin{tabular}{|c|c|c|c|c|c|}
\hline \multirow[b]{2}{*}{ Generic Name } & \multirow[b]{2}{*}{ Patient ID No. } & \multicolumn{2}{|c|}{ Efficacy } & \multirow[b]{2}{*}{$\begin{array}{c}\text { No. (\%) of Safety } \\
\text { End Points Monitored }\end{array}$} & \multirow[b]{2}{*}{$\begin{array}{c}\text { Presence and } \\
\text { Type of Side Effects }\end{array}$} \\
\hline & & $\begin{array}{l}\text { No. (\%) of End } \\
\text { Points Monitored }\end{array}$ & $\begin{array}{l}\text { Targeted Efficacy } \\
\text { Achieved }\end{array}$ & & \\
\hline Ustekinumab & 36 & $\mathrm{NA}$ & No & $1 / 1(100)$ & $\begin{array}{c}\text { Yes }(n=1) \\
\text { Liver enzyme increase } \\
\text { with cholestatis }\end{array}$ \\
\hline Vedolizumab & 49 & $3 / 4(75)$ & No & $2 / 2(100)$ & No \\
\hline Total & 43 requests, 35 patien & $110 / 122(90)$ & $23 / 43(53) \dagger$ & $85 / 91(93)$ & 14 \\
\hline
\end{tabular}

MIBG = metaiodobenzylguanidine, $\mathrm{NA}=$ not applicable.

*A total of 47 requests were approved, but administration of the drug occurred in only 43 of these cases.

tData for this variable are reported in the text as 23 (59\%) of the 39 requests for which efficacy was known.

proposed drug, as background to soliciting patient consent and addressing drug reimbursement issues. In particular, the form contained information about the patient's health care insurance coverage, to facilitate administrative paperwork for drug reimbursement.

Around the world, other similar policies have been developed, mainly for high-cost drugs. ${ }^{9-11}$ However, the policy described here not only addresses the high cost of drugs, but also aims to rationalize off-label and nonmarketed drug use.

The request form for new and expensive drugs is an integral part of the patient care process and can be used for ensuring continuity of care, transparency with the clinical team, and accountability of the prescriber and the clinical pharmacist. Although traditional nonformulary request forms require the prescriber's signature, the request form for new and expensive drugs must also be signed and supported by a clinical pharmacist before the request will be considered.

Some might argue that there is sufficient paperwork for clinicians and that a program such as this is putting more pressure on them. We believe that this 1-year descriptive study shows the feasibility of the request program for new and expensive drugs at the study hospital and its value to support decision-making process in this tertiary care hospital. The 58 requests for new and expensive drugs represented at least Can $\$ 1019365$ (with cost information missing for a few requests), which accounted for $4 \%$ of the annual drug budget (mainly for pediatric indications). Requests were processed efficiently, with a median delay of 1 day.

This study had some limitations. Data were collected only for the first year of application of the policy. In some cases, data for outcomes and safety issues were missing. Further evaluation should be conducted to confirm the long-term applicability and benefits of the program. A research assistant was working part-time on the project, and availability of this resource may have influenced feasibility of this implementation. Applicability to other centres, with consideration of local practices, would have to be studied. Only requests for new and expensive drugs were included and analyzed in this study. Clinicians were not surveyed to determine their satisfaction, but implementation of the program did not encounter any resistance, mainly because clinicians were informed of the need to comply with the policy in order to preserve their access to new and expensive drugs at the study hospital.

\section{CONCLUSION}

This study has illustrated implementation of a drug policy for new and expensive drugs in a mother-child teaching hospital over a 12-month period. This report describes a total of 58 requests for 28 new and expensive drugs (prescribed for a total of 48 patients). Drugs that are new or expensive (or both) represent a challenge for clinicians and hospital stakeholders. Such a policy helps to document not only the usual information collected in nonformulary request forms, but also the level of evidence for using the drug, its place in overall therapy, both efficacy and safety end points, complete patient consent, and a team decision involving both a physician and a pharmacist.

\section{References}

1. Prescribed drug spending in Canada, 2016: a focus on public drug programs. Ottawa (ON): Canadian Institute for Health Information; 2016 [cited 2017 Sep 26]. Available from: https://secure.cihi.ca/free_products/Prescribed $\% 20$ Drug\%20Spending\%20in\%20Canada_2016_EN_web.pdf

2. Chapter 6: Médicaments et services pharmaceutiques. In: Rapport du Vérificateur Général du Québec à l'Assemblée nationale pour l'année 2014-2015. Québec (QC): Vérificateur Général du Québec; 2015 [cited 2017 Sep 26]. Available from: www.vgq.gouv.qc.ca/fr/fr_publications/fr_rapport-annuel/ fr_2014-2015-VOR-Printemps/fr_Rapport2014-2015-VOR-Chap06.pdf

3. National Health Coalition. Against privatization: Canada health coalition demands funding for hospitals. Montréal (QC): Global Research, Centre for Research on Globalization; 2016 [cited 2017 Sep 26]. Available from: www.globalresearch.ca/canada-against-privatization-health-coalitiondemands-funding-for-hospitals/5505912

4. Chase KA. Chapter 4: Medication management. In: Horldford DA, Brown $\mathrm{TR}$, editors. Introduction to hospital and health-system pharmacy practice. Bethesda (MD): American Society of Health-System Pharmacists; 2010. p. 59-78.

5. Massaro F, Gouveia WA. Chapter 34: Applications in hospital pharmacy practice. In: Desselle SP, Zgarrick DP. Pharmacy management: essentials for all practice settings. 2nd ed. New York (NY): McGraw-Hill Medical; 2009: p. 591-7.

6. Corny J, Pelletier E, Lebel D, Bussières JF. Retrospective review of emerging drug use in a mother-child center in Quebec [abstract]. Can J Hosp Pharm. 2015;68(1):82.

7. Corny J, Pelletier E, Bussières JF. Élaboration d'un outil d'aide à la décision pour la prise en charge des thérapies coûteuses émergentes dans un centre 
This single copy is for your personal, non-commercial use only.

For permission to reprint multiple copies or to order presentation-ready copies for distribution, contact CHHP at publications@cshp.ca

universitaire mère-enfant [poster]. In: $5^{\mathrm{e}}$ Colloque annuel du Réseau québécois de revue d'utilisation des médicaments; 2015 [cited 2017 Sep 26]. Available from: http://indicible.ca/urpp/20150414_EMERGENT 4_Affiche.pdf

8. Corny J, Pelletier E, Gaudreault P, Bussières JF. Évolution de la composition et des fonctions du comité de pharmacologie au sein d'un établissement de santé québécois. Pharmactuel. 2015;48(4):213-8. Article in French with English abstract.

9. NSW Therapeutic Advisory Group (TAG): high cost drugs working group: terms of reference. Sydney (Australia): New South Wales Therapeutic Advisory Group; 2009 [2017 Sep 26]. Available from: www.ciap.health.nsw.gov.au/ nswtag/documents/committees/hcdwg-tor.pdf

10. WA hospitals high-cost medicine formulary. East Perth (Australia): Western Australian Therapeutic Advisory Group; 2016 [2017 Sep 26]. Available from: www.watag.org.au/wadep/highcost.cfm

11. Lee J. Hospitals take steps to control drug costs. Mod Healthc. 2014 Nov 29 [2017 Sep 26]. Available from: www.modernhealthcare.com/article/ 20141129/MAGAZINE/311299983

Jennifer Corny, DPharm, is with the Pharmacy Practice Research Unit, Centre hospitalier universitaire Sainte-Justine, Montréal, Quebec.
Camille Cotteret, DPharm, is with the Pharmacy Practice Research Unit, Centre hospitalier universitaire Sainte-Justine, Montréal, Quebec.

Élaine Pelletier, BPharm, MSc, is with the Pharmacy Department and the Pharmacy Practice Research Unit, Centre hospitalier universitaire SainteJustine, Montréal, Quebec.

Philippe Ovetchkine, MD, is with the Pediatrics Department, Centre hospitalier universitaire Sainte-Justine, Montréal, Quebec.

Jean-François Bussières, BPharm, MSC, MBA, FCSHP, FOPQ, is with the Pharmacy Department and the Pharmacy Practice Research Unit, Centre hospitalier universitaire Sainte-Justine, and the Faculty of Pharmacy, Université de Montréal, Montréal, Quebec.

Competing interests: None declared.

\section{Address correspondence to:}

Jean-François Bussières

Pharmacy Department and Pharmacy Practice Research Unit

Centre hospitalier universitaire Sainte-Justine

3175, chemin de la côte Sainte-Catherine

Montréal QC H3T 1C5

e-mail: jf.bussieres@ssss.gouv.qc.ca

Funding: None received. 